\title{
IMPROVING LISTENING SKILL BY ACTIVATING STUDENTS' PRIOR KNOWLEDGE
}

\author{
By Sitti Nurpahmi \\ Nurpabmi@gmail.com
}

\begin{abstract}
This research paper aims at finding whether the students ability in listening can be improved by activating students' prior knowledge. The research conducted at English education study program of faculty of Tarbiyah and education of UIN Alauddin Makassar. This research applied cluster random sampling method. The research data were collected using listening test. It was given at pretest and posttest to know the students' achievement on listening. The data got during research was analyzed by $t$ test. The finding of the study indicated that the experimental group was higher than that of control group. The result of the hypothesis testing showed that the difference of average score was significant $(0.000<0.05)$. This means that there was an improvement of students' achievement after being exposed by activating their prior knowledge. It implies that activating students' prior knowledge can improve students' listening skill.
\end{abstract}

KEY WORDS: Prior knowledge, Listening Skill

\section{A. INTRODUCTION}

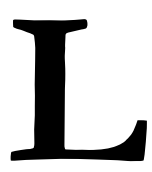

istening is a skill which involve receiving message in spoken form and therefore often referred to as receiptive skill (Harmer, 1991:16). Eventhough it is assumed as a receptive skill, it needs an process to decode the message from the speaker. The listener must be active to process the information listened from the speaker.

Listening is the Cinderella skill in second language learning. It became fashionable again in the 1980s when Krashen's (1982) ideas about comprehensible input gained prominence. By stressing the role of comprehensible input, second language acquisition research has given a major boost to listening. As Rost (1994) points out, of the four language skills - speaking, listening, reading and writing, listening is the most critical for language learning at the beginning stages. Therefore, nowadays listening is assuming greater and greater importance in foreign language classrooms.

The teaching of listening has attracted a greater level of interest in recent years than it did in the past. Now, university entrance exams, exit exams, and other 
examinations often include a listening component, acknowledging that listening skills are a core component of second-language proficiency, and also reflecting the assumption that if listening isn't tested, teachers won't teach it.

Listening is one of the receptive skills and as such it involves students in capturing and understanding the input of English. Reading, the other receptive skill, involves students in understanding and interpreting the written word. Listening is probably more difficult than reading because students often recognise the written word more easily than they recognise the spoken word. Furthermore when reading, students can go back and reread a phrase whereas with listening they only get one chance. With reading, it's the reader who sets the pace whereas with listening it's the speaker or recording that sets the pace (Lucy Pollard, 2008: 1).

Because of these issues, many students find listening difficult. Listening tasks can be very disheartening and demotivating, especially if students have had a previous negative experience. It is therefore important to give our students plenty of opportunities to practise the skill of listening in a supportive environment that helps them to learn. We need to design tasks that help them learn rather than merely testing their abilities. This means that we guide them through the recording, preteach language and highlight the essential points of the recording. This is in contrast to testing, where the teacher simply plays the recording and the students listen and answer questions.

However, careful observation of College English teaching practice has found that the teaching of listening skills is still the weak link in the language teaching process. Despite students having mastered the basic elements of English grammar and vocabulary, their listening comprehension is often weak. Through systematic study of basic English teaching stages at university it has been recognized that while students' integrated skills in reading, writing, translating have been improving, their listening and speaking capabilities have been left behind. The key factor that has been recognized in the preliminary studies is students' limited listening comprehension (Brown, 2006: 2). Futhermore, Listening in another language is considered as a hard job (Richard, 2008: 2).

The prior study that the researcher conducted in field research found that, students need to repeat to play the video four times to be identify information required,while in normal listening test the recording just play once.

Moreover, listening is an mental process that involve critical element in the competent language performance of L2 learners. In the process of comprehension, 
listeners use both bottom-up and top-down processes to comprehend. Knowing the context of a listening text and the purpose for listening greatly reduces the burden of comprehension. Teachers can help students develop strategies with such activities as controlled practice and open-ended listening. Students may have limited general knowledge about a topic. Providing knowledge input will build up their confidence for dealing with listening.

Richard (2008:2) one way to make listening easier is by applying what we know about activating prior knowledge, helping students organize their learning by thinking about their purposes for listening, and if speaking is also a goal of the classroom, using well-structured speaking tasks informed by research.

There has been some recent research (Zeng Ya-jun, 2007, Abbas Pourhosein Gilakjani, and Seyedeh Masoumeh Ahmadi, 2011, Dr. Mohamad Jafre Zainol Abidin, and Suhsun Chang) has found that prior knowledge has positive contribution in language learning.

Based on the previous explanation so the writer is interested in conducting research in improving listening ability by Activating prior knowledge.

\section{B. LITERATURE REVIEW}

Listening is a complex activity, and we can help students comprehend what they hear by activating their prior knowledge. The next section will consider another way teachers can help ease the difficulty of listening: training students in different types of listening.

Brown (2006:2) point out that one very important idea for teaching listening is that listening courses must make use of students' prior knowledge in order to improve listening comprehension. We have known at least since the 1930s that people's prior knowledge has an effect on their cognition. Prior knowledge is organized in schemata (the plural form of schema): abstract, generalized mental representations of our experience that are available to help us understand new experiences. Another way to look at this phenomenon is the idea of scripts. For example, everyone who has been to a restaurant knows that there is a predictable sequence of questions involved in ordering a meal. In the United States these have to do with whether you want soup or salad, the kind of dressing on the salad, choice of side dishes, etc. Even if you do not hear a question, perhaps because the restaurant is too noisy, you can guess from your place in the script what the server is probably asking. Unfortunately, this script does not transfer perfectly from country to country 
because the routine is slightly different in each place. However, when traveling in another country, and eating in a restaurant, you can make certain assumptions about the kinds of questions that will be asked. If food has been ordered but drinks have not, and the server asks another question, you might fairly predict that the question is about the choice of drinks, based on your prior knowledge of what happens in restaurants. Indeed, successful language learners often can be separated from unsuccessful language learners by their ability to contextualize their guesses and use their prior knowledge in this way.

Prior knowledge helps listener to get comprehension from the spoken language. One can easily understand the utterances, they have stored vocabulary related to the topic that they listen.

The idea of prior knowledge is one part of the cognitive model of language processing. That model says that when people listen or read, we process the information we hear both top-down and bottom-up. Top-down means using our prior knowledge and experiences; we know certain things about certain topics and situations and use that information to understand. Bottom-up processing means using the information we have about sounds, word meanings, and discourse markers like first, then and after that to assemble our understanding of what we read or hear one step at a time (Brown, 2006: 3).

Furthermore, Students obviously need both bottom-up and top-down processing skills in listening as well. Students must hear some sounds (bottom-up processing), hold them in their working memory long enough (a few seconds) to connect them to each other and then interpret what they've just heard before something new comes along. At the same time, listeners are using their background knowledge (top-down processing) to determine meaning with respect to prior knowledge and schemata (Brown, 2006: 4).

The cognitive view of language learning sees listening comprehension as being basically the same as reading comprehension and consequently pedagogical practices have been very similar: In a typical lesson, there are "pre" activities, "while" activities, and "post" activities. However, teachers know that, despite our practice, listening is a bit different from reading. For instance, students can skim a text quickly to get a good idea what it's about, but listeners can't skim. The language comes rushing in at them. Listening must be done in real time; there is no second chance, unless, of course, the listener specifically asks for repetition. When students read, cognates (words that are similar in two languages) help understanding. But while 
cognates may look alike on the page, their sounds may be quite different and they may be less useful while listening. Listening also involves understanding all sorts of reductions of sounds and blending of words. There are false starts and hesitations to be dealt with (Brown, 2006: 5).

It is beneficial for listening course teachers to bear in mind that activating students' stored knowledge structure (schemata) to enhance comprehension and creating new schemata are far more important than imparting new knowledge of the language system. Research has also shown that the accumulation of schemata contributes most to efficient comprehension and retention of new listening material which are getting more difficult as students progress along the way (Rumelhart, 1997).

Schemata involved in listening can be categorized into two major types: language schema and knowledge schema.

1. Language schema. As the basis for listening comprehension, language schema refers to the phonological, lexical, syntactic and grammatical knowledge that students have already grasped. It is unimaginable to achieve satisfactory comprehension of the listening material without proper storage of the four basic language knowledge (Widdowson, 1978). The following are two examples. Dialogue 1 (lexical schema) W : Lots of people enjoy dancing, do you?

$\mathrm{M}:$ Believe it or not, that is the last thing I want to do.

Q : What does the man mean? (Original question from CET 6, Jan. 2002)

Dialogue 2 (grammatical schema)

W : Oh, my car broke down again! How can I get to the office?

M : Had my car been repaired, I would be happy to lend it to you.

Q : what does the man mean? (Original question from CET 6, Jan. 2002)

2) Knowledge schema. In listening test, a lot of dialogues are taken from typical daily life situations. It is generally believed that in these typical situations like hotel, restaurant, post office, hospital, book store, library, airport, bank...etc., the relationship between interlocutors and ways of conversing are comparatively fixed. These common knowledge when absorbed and stored in people's memory are called schemata by cognitive psychologists (Widdowson, 1978). The following is a good example taken from authentic exam paper. W : Gorge, look at the long waiting line. I am glad you've made a reservation. 
M : More and more people enjoy eating out now. Beside, this place is especially popular with the overseas students.

Q : Where did the conversation most probably take place? (original test question from CET-4, June 2003)

Cognitive psycholinguists argue that both language schema and knowledge schema are crucial for enhancing comprehension. Put specifically, schemata are found significant in six aspects according to Anderson (1983):

a. an ideational scaffolding for assimilating text information;

b. helpful for attention distribution;

c. helpful for inferential elaboration;

d. enabling listener to search information from memory in an orderly way;

e. useful for editing and summarizing;

f. helpful for inferential reconstruction.

\section{RESEARCH METHODOLOGY}

According to Gay (2006:233) "experimental research is the only type of research that can test hypothesis to establish cause-effect relationship. It represents the strongest chain of reasoning about the links between variables.

The design of the research was quasi experimental with The nonequivalent control group design as follows:

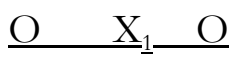

$$
\mathrm{O} \quad \mathrm{X}_{2} \mathrm{O}
$$

(Gay, 2006:255)

O : Pre-test Listening or Post-test Listening

$\mathrm{X}_{1}$ : experimental group

$\mathrm{X}_{2}$ : Control group

Population of this research is the third semester students of Tarbiyah aculty of UIN Alauddin Makassar Academic Year 2013/2014. They consist of six groups. The researcher took two groups as sample. Each group consists of 40 students. The students were chosen by using cluster random sampling. So there were 80 students taken as sample in this research. 
Sitti Nurpahmi, Improving Listening Skill By Activating Students' Prior Knowledge

\section{D.FINDING AND DISCUSSION}

Based $\mathrm{n}$ data analysis it shows that the students' pretest score and percentage of listening for experimental and control class.

Table 1 The Percentage of Students' Pretest Score of Listening

\begin{tabular}{|c|c|c|c|c|c|}
\hline \multirow{2}{*}{ Classification } & \multirow{2}{*}{ Score } & \multicolumn{2}{|c|}{ Experimental Class } & \multicolumn{2}{|c|}{ Control Class } \\
\hline & & Frequency & Percentage & Frequency & Percentage \\
\hline Very Good & 4 & - & - & - & - \\
\hline Good & 3 & 6 & 15 & 7 & 17.50 \\
\hline fair & 2 & 32 & 85 & 33 & 82.50 \\
\hline Poor & 1 & - & - & - & - \\
\hline Very Poor & 0 & - & - & - & - \\
\hline Total & & 40 & $100 \%$ & 40 & $100 \%$ \\
\hline
\end{tabular}

Based on the table 1 above, it is known that most of the students for experimental class was in fair category, 32 students (85\%) got fair and 6 student $(85 \%)$ got good score. Besides in control class, the score was categorized also in average category, from the 40 respondents, the data indicated that 33 students $(82.50 \%)$ got average and 7 students $(17.50 \%)$ got good score.

Based on the data it means that two classes were almost the same. Both of them were classified in very poor categories.

The following shows the percentage of students' posttest score of listening who were taught by activating prior knowledge, was different from those who were taught without activating prior knowledge.

Table 2 The Percentage of Students' Posttest Score of Listening

\begin{tabular}{cccccc}
\hline \multirow{2}{*}{ Classification } & Score & \multicolumn{2}{c}{ Experimental Class } & \multicolumn{2}{c}{ Control Class } \\
\cline { 3 - 6 } & & Frequency & Percentage & Frequency & Percentage \\
\hline Very good & 4 & 6 & $15 \%$ & 3 & $7.50 \%$ \\
Good & 3 & 31 & $77.50 \%$ & 16 & $40 \%$ \\
Fair & 2 & 3 & $7.50 \%$ & 21 & $52.50 \%$ \\
Poor & 1 & 0 & $0 \%$ & 0 & $\%$
\end{tabular}


Volume I, Number 01, June 2015

\begin{tabular}{cccccc} 
Very poor & 0 & 0 & $0 \%$ & 0 & $\%$ \\
\hline Total & 40 & $100 \%$ & 40 & $100 \%$ \\
\hline
\end{tabular}

The data above shows that the Students' listening skill of experimental class in posttest increased, 31 students $(77.50 \%)$ got good, 6 students $(15 \%)$ got very good score and 3 students $(7.50 \%)$ got fair score. While, in control class, 2 student $(7.50 \%)$ got very good, 16 students (40\%) got good score classification and 21 (52.50) got average score.

Based on the data it shows that the students score in both classes increase. The result of students' pretest score was gained by the students can be seen in a table as follows:

Table 3 The Mean Score and Standard Deviation of Students' Pretest in Listening

\begin{tabular}{lcc}
\hline \multicolumn{1}{c}{ Class } & Mean Score & Standard Deviation \\
\hline Experimental & 2.13 & 7.363 \\
Control & 2.16 & 7.468 \\
\hline
\end{tabular}

The table 3 above shows that the mean score of students' listening pretest of experimental class is 2.13 which is categorized as fair classification and control class is 2.16 which is categorized as fair classification too. Therefore, based on the table above, we concluded that the students' mean score of experimental class is nearly same with the control class. It means that there is not significantly different between the Students' listening skill both experimental and control classes before treatment.

Because the students pretest was nearly at the same level, the treatment was conducted to the both groups. The experimental class was taught English by activating priorknowledge and control class was taught the same materials without activating prior knowledge.

The mean score and standard deviation are presented in the following table to find out the difference between the posttest score of experimental and control classes. 
Sitti Nurpahmi, Improving Listening Skill By Activating Students' Prior Knowledge

Table 4 The Mean Score and Standard Deviation of Students'

Posttest

\begin{tabular}{lcc}
\hline \multicolumn{1}{c}{ Class } & Mean Score & Standard Deviation \\
\hline Experimental & 3.1 & 5.025 \\
Control & 2.53 & 6.827 \\
\hline
\end{tabular}

The table 4 above shows that the mean score of both groups are different after being given treatment. The mean score of experimental class is 3.1 which is categorized as good and control class is 2.53 which is categorized is fair and standard deviation of experimental class is 5.025 and standard deviation of control class is 6.827.

\section{Test of significant (t-test)}

Inferential analysis was used to test the hypothesis. The researcher used t-test (test of significance) for independent sample test. This is a test to know the significant difference between the result of students' mean scores in posttest in control class and experimental class after being taught by activating prior knowledge. The level of significance $(\alpha)=0.05$, then the result of the t-test is presented in the following table:

Table.5 The p-Value of t-test of Student Achievement on Control and Experimental Classes

\begin{tabular}{lccl}
\hline \multicolumn{1}{c}{ Variables } & p-value & $(\boldsymbol{\alpha})$ & \multicolumn{1}{c}{ Remarks } \\
\hline $\begin{array}{l}\text { Pretest of control and } \\
\text { experimental classes }\end{array}$ & 0.343 & 0.05 & $\begin{array}{l}\text { Not significantly } \\
\text { different }\end{array}$ \\
$\begin{array}{l}\text { Posttest of control and } \\
\text { experimental classes }\end{array}$ & 0.00 & 0.05 & $\begin{array}{l}\text { Significantly } \\
\text { different }\end{array}$ \\
\hline
\end{tabular}

Based on the result of data analysis as summarized in table. 5 above in pretest of control and experimental class, the researcher found that the Probability Value is higher than alpha $(\alpha)(0.343>0.05)$ which means that there is no significant difference in pretest. While on posttest of control and experimental class, the researcher found that the $\mathrm{p}$-value $(0.00<0.05)$ and the degree of freedom 78 .The mean score of experimental and control classes in posttest were remarked significantly different. It indicated that the alternative hypothesis $\left(\mathrm{H}_{1}\right)$ was accepted 
and, of course, the null hypothesis $\left(\mathrm{H}_{0}\right)$ was rejected. It showed that the application of activating students' prior knowledge in teaching listening significantly increase Students' listening skill.

This implies that the activating students' prior knowledge should be taken for granting as one of the techniques that improve students' listening skill to the participants of English education study program of Tarbiyah and Education Faculty of UIN Alauddin Makassar.

Relating to collected data through the pretest and posttest, the comparison of the improvement of students' achievement of experimental and control class can be proved by analyzing the posttest result. It was concluded that after giving treatment, there was a significant progress toward students' listening skill.

The mean score of experimental and control group increased after they were given treatments. The experimental group learnt by activating students; prior knowledge while the control group learnt by using the conventional method. It indicates that the the application of activating students' prior knowledge can improve students listening skill.

The improvement of students' listening skill was marked by the result of the posttest occurring in the both experimental and control group. However, the improvement rate of the experimental group was higher than control group.

What is found through this research support the previous finding and theory that schemata theory can improved students listening skill. As Richard (2008:2) point out that one way to make listening easier is by applying what we know about activating prior knowledge, helping students organize their learning by thinking about their purposes for listening.

Moreover, it is also support some recent research (Zeng Ya-jun, 2007, Abbas Pourhosein Gilakjani, and Seyedeh Masoumeh Ahmadi, 2011, Dr. Mohamad Jafre Zainol Abidin, and Suhsun Chang that has found that prior knowledge has positive contribution in language learning.

\section{BIBLIOGRAPHY}

Anderson, A. \& Lynch, T. (1988). Listening. Oxford: Oxford University Press.

Brown, Douglas. (2001). Teaching by Principle: An Interactive Approach to Language Pedagogy. New York: US. Addison Wesley Longman, Inc.

Brown Steven. 2006. Teaching Listening. New York: Cambridge University Press. 
Eysenck, M. W. 2001. Principles of cognitive psychology. Philadelphia: Psychology Press.

Lucy Pollard. 2008. Lucy Pollard's Guide to Teaching English.

Richards. Jack C. 2008. Teaching Listening and Speaking. New York: Cambridge University Press.

Richards, J.C., Platt, J., Platt, H.. Longman Dictionary of Language Teaching \& Applied Linguistics. Longman Group UK Limited. 1992.

Rixon, S.. Developing Listening Skills. London: Macmillan Publishers Ltd.1986.

Rost, M.. Listening in Action: Activities for Developing Listening in Language Education. Hemel Hempstead: Prentice Hall International. 1991.

Rumelhart, D. E. 1997. The architecture of mind: A connectionist approach. Mass.: MIT Press.

Widdowson, H. G. 1978. Teaching language as communication. Oxford: Oxford University Press. 